\title{
WEEKLY RADIAL INCREMENT OF BALSAM FIR IN QUEBEC AS RELATED TO MCLINTOCK'S TREE CLASSIFICATION ${ }^{1}$
}

\author{
By J. D. GAGNON ${ }^{2}$
}

\section{$A B S T R A C T$}

Radial increments of 38 balsam fir trees (Abies balsamea (L.) Mill.) differing in height, crown class and vigour, were studied to determine if their correlation with the McLintock classification was better than that with either total height, crown class, vigour class or crown ratio. Measurements at weekly intervals during the 1961 growing season have shown the superiority of the McLintock tree classification over the other four. It seems, therefore, that the interaction of the factors involved in McLintock classification is essentially valid even for very short predictions.

\section{RESUME}

Le présent travail a été abordé dans le but de déterminer si la classification d'arbres, d'après la méthode de McLintock, est supérieure à celles basées uniquement soit sur la hauteur totale, soit sur le coefficient de cîme, l'étage ou la vigueur de l'arbre. A cet effet, 38 sapins baumiers (Abies balsamea (L.) Mill.) de hauteur, classe de cîme et vigueur différentes ont été étudies. Des mesures échelonnés hebdomadairement durant la période de croissance de l'année 1961, ont montré la supériorité de la méthode de McLintock sur les quatre autres. Il semblerait donc que l'action réciproque des facteurs mis en évidence d'aprés McLintock, est essentiellement valide même pour une très courte période.

INTRODUCTION

If thinning can be justified economically, the choice of the tree to reserve must be judiciously made. McLintock (1948) showed that his method was a reliable guide in the spruce-fir region of northeast Maine. The present study was made to find out how the McLintock classification worked for extremely short periods in the Quebec region and how it compares to those based on total height, crown class, vigour class or on the ratio of the length of the living crown over the total height of the tree.

GENERAL

The essence of the classification developed by McLintock in 1948 comprised three variables: crown class, live crown ratio, and vigour. Each of these variables are sub-divided into three sub-classes. The whole classification is represented in Table 1.

TABLE 1.

Basic Factors of McLintock's Tree Classification (FROM MCLINTOCK, 1948)

\begin{tabular}{|c|c|c|c|}
\hline $\begin{array}{l}\text { Variable } \\
\text { Rating in points }\end{array}$ & 3 & 2 & $\mathbf{1}$ \\
\hline Crown class & Dominant and co-dominant & Intermediate & Overtopped \\
\hline Live crown ratio & $0.7-1.0$ & $0.4-0.6$ & $0.1-0.3$ \\
\hline Vigour & $\mathbf{I}$ & II & III \\
\hline
\end{tabular}

${ }^{1}$ Contribution No. 510, Forest Research Branch, Dept. of Forestry, Canada.

Research Officer Forestry, Forest Research Branch, Dept. of Forestry, Quebec District, Sillery, Quebec. Biographical Sketch in Forestry Chronicle, June, 1961, Vol. 37, No. 2. 
In estimating these three variables, McLintock stated:

"Overtopped does not mean the same as suppressed; a fir may be overtopped but still not necessarily suppressed because it can grow satisfactorily in the understorey.

Vigour is judged by density, character, and color of foliage, length of shoot growth, condition of the bark and general appearance of the crown."

The classification is thus based on the concept that growth is a function of crown class, live crown ratio, and vigour. For example, on a given site, the number of points assigned to a 50-foot tall dominant balsam fir with 15 feet of live crown and of poor vigour, will be as follows: for its dominance: 3 points; for its crown ratio: 1 point; for its vigour: 1 point; making a total of 5 points. According to the classification the potential growth of any given tree will vary proportionately to the points given, that is between 3 and 9.

\section{Experimental Details}

Data were collected at Valcartier, 15 miles north of Quebec city from a 30-50-year-old balsam fir stand. The site, as assessed by lesser vegetation (Dryopteris-Oxalis) and site index (52 feet) is, according to Linteau (1955) Class I for balsam fir. The height of the selected trees varied from 30 to 50 feet, and the diameter at breast height ranged from 4 to 6 inches.

Crown class, live crown ratio and vigour class varied widely between the 38 trees graded according to McLintock's tree classification.

The radial increment of each tree was measured at regular weekly intervals using a dial gauge dendrometer similar to the one described by Belyea, Fraser and Rose (1951). Measurements of radial growth were made on the south side of the tree at about 4.5 feet above ground level. The first radial readings were made on May 17 when some snow was still on the ground, and the last readings on August 9, which is about the end of the growing season (Ray, 1936.)

\section{Results AND Discussion}

Results of analysis of the relationship between radial increment and total height, crown class, crown ratio, vigour class and McLintock's tree classification are summarized in Table 2.

The superiority of the method developed by McLintock over the four others is evident. In the McLintock method, $33.6 \%$ of the variation in radial growth is explained, for vigour class $10.9 \%$ is explained while in the other two methods less than $1 \%$ of such variation is explained.

Figure 1 illustrates the weekly average cumulative radial increment for the 1961 growing season for 38 trees classified according to the McLintock tree classification. At the initiation of growth in the spring, there is no apparent relationship between radial increment and the McLintock classification. As

\footnotetext{
sased on height of dominant and co-dominant fir and black spruce at 50 years.

- Ray, R. G. 1936. A report on phenological observations at Valcartier Forest Experimental Station for the season 1935. Canada, Dept. of Mines and Resources, Lands, Parks and Forests Branch, Dominion Forest Service (unpublished).
} 
TABLE 2.

Values of the Correlation Coefficients Between Different Methods of Tree Classification and Radial InCREMEnt of 38 Trees

\begin{tabular}{lcc}
\hline \multicolumn{1}{c}{ Methods } & Correlation coefficients & Significance \\
\hline Total height & .03 & Not significant \\
Crown class & .09 & Not significant \\
Live crown ratio & .14 & Not significant \\
Vigour class & .33 & Significant \\
McLintock & .58 & Highly-significant \\
\hline
\end{tabular}

(For $\mathrm{p}=.01, \mathrm{r}=.40 ;$ for $\mathrm{p}=.05, \mathrm{r}=.31$ )

the growing season advances, a definite relationship becomes well marked by July 5 and continues to be evident up to the end of the season except perhaps for the trees in classes 4 and 5. However, if the extreme classes are considered, it is obvious that the radial increment during the whole growing season is much better for the highest than for the lowest graded trees.

Irrespective of tree class, in 1961 radial increment slowed down or declined about the beginning of August. The fluctuations at this time, are, according to Warrack and Joergensen (1950) caused by dehydration of the cell tissues which increases shrinkage in tree trunk. Such fluctuations in growth seem to happen in many species at about the end of the growing season (Belyea, Fraser and Rose, 1951).

The validity of the features involved in McLintock's tree classification, when applied to immature trees growing on a given site-type, can hardly be questioned. They are the end result of growth factors which, by their interaction, have influenced or are still influencing individual trees. In a stand there are always trees which, for one reason or another, exhibit better growth than their neighbours and the McLintock tree classification takes this into consideration when characterizing each tree.

\section{CONCLUSION}

From this short study of the relationship between the radial increment of fir trees growing on a good site in Quebec and five methods of tree classification, it is evident that the method developed by McLintock gives a better correlation than those based on single factors of total height, crown class, vigour class or on live crown ratio alone. Although limited to one locality, the data, nevertheless, suggest that for stands and sites similar to the one studied, the method developed by McLintock could be of value in the choice of crop trees in the Quebec region.

\section{REFERENCES}

BELYEA, F. M., D. A. FRASER, and A. H. ROSE. 1951. Seasonal growth of some trees in Ontario. For. Chron. 27: 300-305.

LINTEAU, A. 1955. Forest site classification of the northeastern coniferous section boreal forest region Quebec. Canada, Dept. Northern Affairs and National Resources, Forestry Branch, Bull. 118.

McLINTOCK, THOMAS F. 1948. Evaluation of tree risk in the spruce-fir region of the Northeast. Northeast. Forest Sta. Paper No. 16.

ROWE, J. S. 1959. Forest regions of Canada. Canada, Dept. Northern Affairs and National Resources, Forestry Branch, Bull. 123.

WARRACK, G. and C. JOERGENSEN. 1950. Precision measurements of radial growth and daily radial fluctuations in Douglas fir. For. Chron. 26: 52-66. 


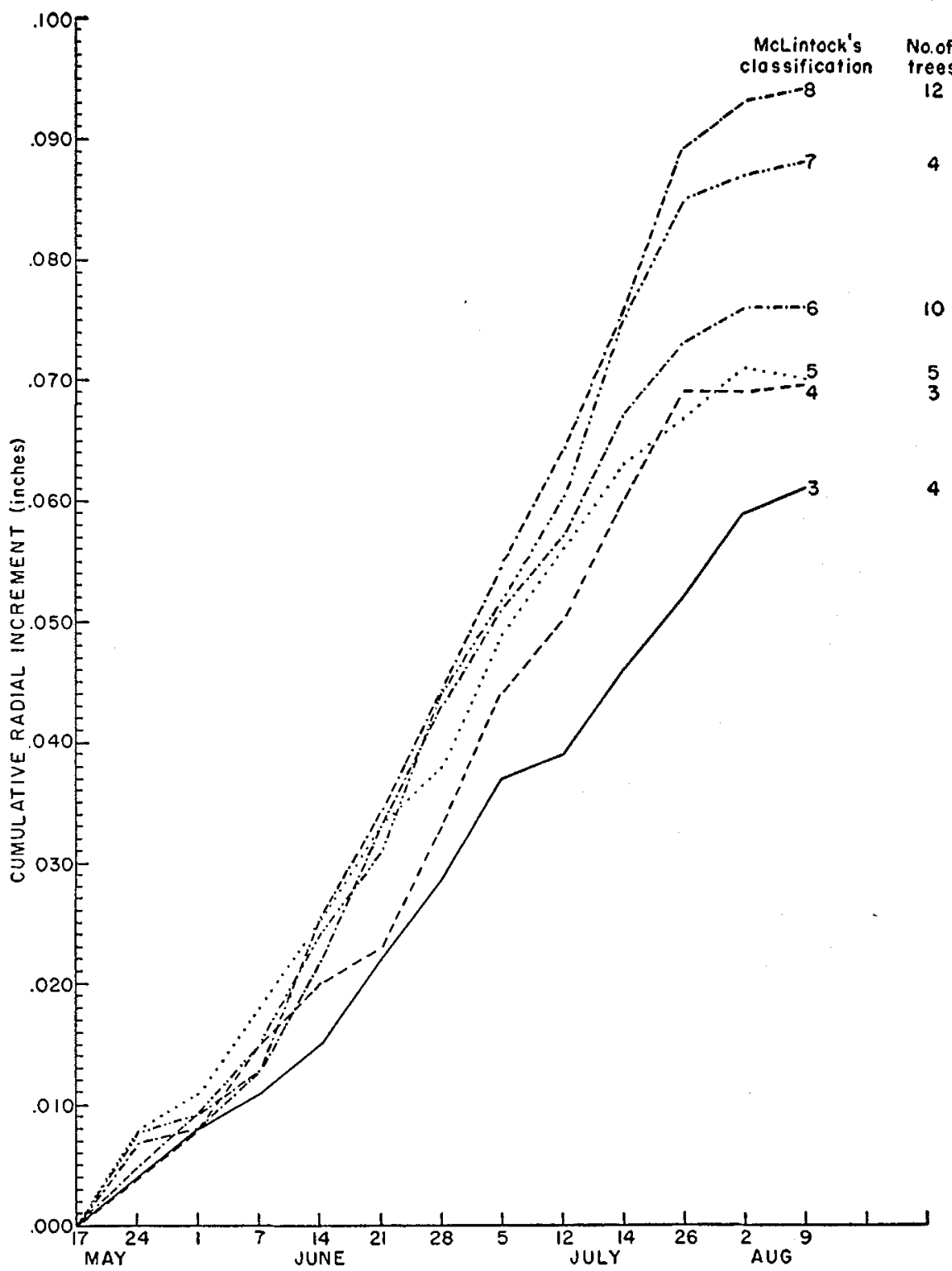

FIGURE I The relationship between weekly overage fir radial increment, 196I, and the McLintock tree clossification 